\title{
Acclimatization contributes to stable anaerobic digestion of organic fraction of municipal solid waste under extreme ammonia levels: Focusing on microbial community dynamics
}

Yan, Miao; Fotidis, Ioannis ; Tian, Hailin; Khoshnevisan, Benyamin; Treu, Laura; Tsapekos, Panagiotis; Angelidaki, Irini

Published in:

Bioresource Technology

Link to article, DOI:

10.1016/j.biortech.2019.121376

Publication date:

2019

Document Version

Peer reviewed version

Link back to DTU Orbit

Citation (APA):

Yan, M., Fotidis, I., Tian, H., Khoshnevisan, B., Treu, L., Tsapekos, P., \& Angelidaki, I. (2019). Acclimatization contributes to stable anaerobic digestion of organic fraction of municipal solid waste under extreme ammonia levels: Focusing on microbial community dynamics. Bioresource Technology, 286, [121376].

https://doi.org/10.1016/j.biortech.2019.121376

\section{General rights}

Copyright and moral rights for the publications made accessible in the public portal are retained by the authors and/or other copyright owners and it is a condition of accessing publications that users recognise and abide by the legal requirements associated with these rights.

- Users may download and print one copy of any publication from the public portal for the purpose of private study or research.

- You may not further distribute the material or use it for any profit-making activity or commercial gain

- You may freely distribute the URL identifying the publication in the public portal 
Acclimatization contributes to stable anaerobic digestion of organic fraction of municipal solid waste under extreme ammonia levels: Focusing on microbial community dynamics

Miao Yan ${ }^{a}$, Ioannis A. Fotidis ${ }^{\text {a,* }}$, Hailin Tian ${ }^{a}$, Benyamin Khoshnevisan ${ }^{\text {a }}$, Laura Treu

b, Panagiotis Tsapekos a , Irini Angelidaki a

${ }^{a}$ Department of Environmental Engineering, Technical University of Denmark, Bygningstorvet Bygning 115, DK-2800 Kgs. Lyngby, DK

${ }^{\mathrm{b}}$ Department of Biology, University of Padova, Via U. Bassi 58/b, 35121 Padova, Italy

*Corresponding Author: Ioannis A. Fotidis, Department of Environmental Engineering, Technical University of Denmark, Bygningstorvet Bygning 115, DK-2800 Kgs. Lyngby, Denmark, Phone: (+45) 45251418; Fax: (+45) 45933850; e-mail: ioanf@env.dtu.dk 


\begin{abstract}
The organic fraction of municipal solid waste (OFMSW) is an abundant and sustainable substrate for the anaerobic digestion (AD) process, yet ammonia released during OFMSW hydrolysis could result in suboptimal biogas production. Acclimatized ammonia tolerant microorganisms offer an efficient way to alleviate ammonia inhibition during AD. This study aimed to achieve an efficient AD of OFMSW under extreme ammonia levels and elucidate the dynamics of the acclimatized microbial community. Thus, two mesophilic continuous stirred tank reactors (CSTR), fed only with OFMSW, were successfully acclimatized up to $8.5 \mathrm{~g} \mathrm{NH}_{4}{ }^{+}-\mathrm{N} / \mathrm{L}$, and their methane yields fluctuated less than $10 \%$, compared to the methane yields without ammonia addition. Microbiological analyses showed that Methanosaeta concilii and Methanosarcina soligelidi were the dominant methanogens at low and high ammonia levels, respectively. Whilst, a unique metabolic pathway shift, from aceticlastic to hydrogenotrophic methanogenesis, of $M$. soligelidi was identified during the acclimatization process.
\end{abstract}

\title{
Keywords
}

Ammonia acclimatization; Hydrogenotrophic pathway; Aceticlastic pathway; metabolic pathway shift; Methanosarcina soligelidi 


\section{Introduction}

The increasing global need for natural resources and consumer goods leads to vast amounts of municipal solid waste (MSW). In 2018, more than 2.5 Mt of MSW were generated in the European Union (Eurostat, 2018), with $46 \%$ of them been organic (OFMSW: organic fraction of MSW) (Hoornweg and Bhada-Tata, 2012). Improper treatment methods of OFMSW can cause environmental and health issues (Fisher, 2006). Currently, most of the MSW is treated in one of the four ways: landfilling (24\%), incineration (28\%), recycling (29\%), and composting (16\%) (Eurostat, 2018). Landfilling and incineration methods do not take advantage of the organic faction and the nutrients of OFMSW and can lead to extra greenhouse gas emissions (Fisher, 2006; Eurostat, 2018). At the same time, huge consumption and shortage of fossil fuels motivate researchers to find alternative energy sources. Thus, new treatment technologies must be developed to not only offset the use of fossil fuels but also maximize the reuse of the vast amounts of the OFMSW and thereby maintain and recycle the useful nutrient back to agriculture.

Anaerobic digestion (AD) is a process that can convert organic waste into sustainable energy (biogas), via a series of interrelated microbial metabolisms (Campanaro et al., 2018). The AD process is divided in four steps (i.e. hydrolysis, acidogenesis, acetogenesis and methanogenesis), which are mediated primarily by bacteria and archaea (Angelidaki et al., 2011). In addition, the liquid product of the AD process (digestate) contains high levels of nitrogen and phosphorus, which can be potentially reused as biofertilizer or after extraction, as supplement for fermentation processes. In spite of these benefits, the degradation of OFMSW produces ammonia, a by-product from the catabolism of proteins, which can be toxic to the AD process, resulting in poor operational stability and reduced methane production efficiency (Tian et al., 2018b). 
Total ammonia (TAN) is the sum of ammonium ions $\left(\mathrm{NH}_{4}^{+}\right)$and free ammonia (FAN, $\mathrm{NH}_{3}$ ), while FAN exists in an equilibrium defined by the $\mathrm{pH}$ and the temperature (Tian et al., 2017). As Koster and Lettinga (1988) reported, when ammonia concentrations ranged from 4 to $5.7 \mathrm{~g} \mathrm{NH}_{4}{ }^{+}-\mathrm{N} / \mathrm{L}$, more than $56 \%$ of the methanogenic activity was inhibited in a granular sludge reactor. The reason is that FAN is freely membrane-permeable and hence, decreases methanogenic activity by interfering with the natural intracellular biological pathways of the methanogens (e.g. inhibiting specific methane synthesizing enzyme reaction) (Sprott and Patel, 1986). It is generally accepted that acetoclastic methanogens are more sensitive to ammonia toxicity compared to hydrogenotrophic methanogens (Schnürer and Nordberg, 2008). For example, hydrogenotrophic methanogenic pathway (coupled with syntrophic acetate oxidation) became dominant (by replacing the acetoclastic pathway) in a semi-continuous lab-scale anaerobic digester, when ammonia exceeded $3 \mathrm{NH}_{4}{ }^{+}-\mathrm{N}$ g/L (Wiegant and Zeeman, 1986). However, there is conflicting information in the literature about the sensitivity of acetoclastic methanogens to ammonia, with few researchers reporting that different members of the acetoclastic Methanosarcina spp. could develop tolerance to ammonia toxicity.

Overall, the ammonia inhibition levels are case sensitive and are defined by the nature of substrate, the inoculum, the reactor type, the operating parameters $(\mathrm{pH}$ and temperature), the mixing and the acclimatization period. For example, 50\% inhibition was observed at 3.9 and $5.6 \mathrm{~g} \mathrm{NH}_{4}{ }^{-}-\mathrm{N} / \mathrm{L}$ in mesophilic and thermophilic batch reactors, respectively that were digesting OFMSW (Liu et al., 2015). While another study found that $1 \mathrm{~g} \mathrm{NH}_{4}{ }^{+}-\mathrm{N} / \mathrm{L}$ in MSW's leachate was enough to inhibit the methane production with $25 \%$ loss in a mesophilic expanded granular sludge bed reactor (Nielsen and Angelidaki, 2008). Stepwise acclimatization to high ammonia levels is a common method used to 
increase ammonia tolerance in the AD microbiome (Akindele and Sartaj, 2018; Tian et al., 2018a). In such a process, mesophilic methanogenic consortia were successfully acclimatized to $5 \mathrm{~g} \mathrm{NH}_{4}{ }^{+}-\mathrm{N} / \mathrm{L}$ (at $\mathrm{pH}$ 7.50) in batch reactors, with OFMSW as substrate (Tian et al., 2018b). However, acclimatization in continuous reactors to overcome ammonia inhibition and improve methane production efficiency of OFMSW has never been reported.

Therefore, the preliminary aim of the present study was to achieve an efficient and stable continuous anaerobic degradation of OFMSW under extreme ammonia levels (>7 $\mathrm{g} \mathrm{NH}_{4}{ }^{+}-\mathrm{N} / \mathrm{L}$ ). While, the main aim of the study was to elucidate the dynamics of the microbial community under different ammonia levels. To realize these aims, two continuous stirred tank reactors (CSTR) were fed with OFMSW, while a stepwise ammonia acclimatization process was followed.

\section{Material and methods}

\subsection{Inoculum and feedstock}

The inoculum used to start up the two CSTR reactors originated from the mesophilic $\left(37^{\circ} \mathrm{C}\right)$ anaerobic digesters, which run for 4 months fed with OFMSW. The substrate used in this study was OFMSW treated with the biopulping process to increase the biodegradability by Gemidan Ecogi A/S. The substrate was kept at $-20^{\circ} \mathrm{C}$ until use, when thawed at room temperature and diluted with distilled water to a fixed TS content of $60 \mathrm{~g}$ VS/kg. The characteristics of the inoculum and the biopulp are presented in Table 1.

Table 1. Characteristics of inoculum and substrate

\begin{tabular}{llll}
\hline Parameter & Unit & Inoculum (SD) & Biopulp (SD) \\
\hline
\end{tabular}




\begin{tabular}{llll}
\hline Total solids (TS) & $\mathrm{g} / \mathrm{kg}$ & $38.61(0.34)$ & $60.52(0.52)$ \\
Volatile solids (VS) & $\mathrm{g} / \mathrm{kg}$ & $24.07(0.35)$ & $52.11(0.55)$ \\
$\mathbf{p H}$ & - & 8.38 & 3.90 \\
Total ammonia & $\mathrm{g} \mathrm{NH} 4^{+}-\mathrm{N} / \mathrm{L}$ & $3.80(0.01)$ & $0.40(0.01)$ \\
nitrogen (TAN) & & & $0.004(0.01)$ \\
Free ammonia & $\mathrm{g} \mathrm{NH} 3-\mathrm{N} / \mathrm{L}$ & $0.896(0.01)$ & \\
nitrogen (FAN) & & & $1.70(0.03)$ \\
Total Kjeldahl & $\mathrm{g} \mathrm{N} / \mathrm{L}$ & $5.38(0.25)$ & \\
Nitrogen (TKN) & & & \\
\hline
\end{tabular}

* SD: standard deviation.

\subsection{Experimental setup}

Two CSTR reactors (i.e. R1 and R2), with total and working volume of 4.5 and $3 \mathrm{~L}$, respectively, were fed with OFMSW for 159 days with an organic loading rate of $2.5 \mathrm{~g}$ VS/L/day where timer was used to control feeding peristaltic pump to inject $75 \mathrm{ml}$ OFMSW per 12 hours. Each reactor was equipped with an influent and an effluent bottle, and a feeding peristaltic pump. Electrical heating jackets maintained the reactors' temperature at $37^{\circ} \mathrm{C}$ and intermittent stirring with the rate of $30 \mathrm{~s} / \mathrm{min}$ was applied for mixing the reactor content (worked $34 \mathrm{sec}$ every $56 \mathrm{sec}$ ). Water-displacement gas meters were used to measure biogas production. The TAN levels of the influent and the reactor content were increased stepwise from 1.1 to $9.5 \mathrm{~g} \mathrm{NH}_{4}{ }^{+}-\mathrm{N} / \mathrm{L}$ with the addition of urea $\left(\mathrm{CO}\left(\mathrm{NH}_{2}\right)_{2}\right)$ and ammonium chloride $\left(\mathrm{NH}_{4} \mathrm{Cl}\right)$. To be more specific, every increase of TAN ( $1-1.5 \mathrm{~g} \mathrm{NH}_{4}{ }^{+}-\mathrm{N} / \mathrm{L}^{-1}$ each step) both inside the reactor and the feedstock in the influent bottle was implemented when there were no significant decrease (more than $85 \%$ 
of methane yield during the baseline period (P1)). The whole experiment was divided into seven phases as presented in Table 2 .

Table2. The CSTR reactors experimental design

\begin{tabular}{ccccc}
\hline Phase & Days & TAN & \multicolumn{2}{c}{ Extra added ammonia } \\
& & & CO(NH$)_{2}$ & NH$_{4} \mathbf{C l}$ \\
& & $\left(\mathbf{g ~ N H}_{4}{ }^{+}-\mathbf{N} / \mathbf{L}\right)$ & $\left(\mathbf{g ~ N H}_{4}{ }^{-} \mathbf{N} / \mathbf{L}\right)$ & $\left(\mathbf{g ~ N H}_{4}{ }^{+} \mathbf{N} / \mathbf{L}\right)$ \\
\hline P1 & $0-30$ & 1.1 & 0 & 0 \\
P2 & $31-51$ & 4 & 1 & 1.9 \\
P3 & $52-66$ & 5 & 2 & 1.9 \\
P4 & $67-74$ & 6 & 2 & 2.9 \\
P5 & $75-89$ & 7 & 3 & 2.9 \\
P6 & $90-127$ & 8.5 & 4 & 3.4 \\
P7 & $128-159$ & 9.5 & 4.5 & 3.9 \\
\hline
\end{tabular}

\subsection{Analyses}

\subsubsection{Chemical analyses}

Methane concentration was measured with the gas chromatography as described by APHA (2005). VFA levels were analysed with gas chromatograph (TRACE 1300 from Thermo Scientific) equipped with flame ionization detector and a DB-FFAP fused silica capillary column. PHM99 LAB pH meter (RadiometerTM) was used to measure the $\mathrm{pH}$. TS, VS, TAN and TKN, were determined according to Angelidaki and Ahring (1993a). 


\subsubsection{Microbial analysis}

Five triplicate samples were taken from both reactors on days $33(\mathrm{P} 1), 55(\mathrm{P} 2), 77$ (P3), $92(\mathrm{P} 5)$ and $162(\mathrm{P} 7)$ and analysed using 16S rRNA gene sequencing technique to elucidate the microbial community shift. After cleaning step with Phenol:Chloroform: Isoamyl Alcohol (25: 24: 1), genomic DNA were extracted using DNeasy PowerSoil@ (QIAGEN GmbH, Hilden, Germany). PCR amplification using universal primers $515 \mathrm{~F} / 806 \mathrm{R}$ was performed on the V4 region of $16 \mathrm{~S}$ rRNA gene and the amplicons were sequenced using MiSeq desktop sequencer at Ramaciotti Centre for Genomics (Sydney, Australia. Raw reads were deposited in Sequence Read Archive (SRA) database (http://www.ncbi.nlm.nih.gov/sra) with the name of SUB5320995.

The raw data were processed using CLC Workbench software (11.0.1) with the Microbial genomics module plugin. A trimming procedure was used to low-quality reads according to default parameters provided by the software and paired sequences were merged. Chimera crossover filter was also applied. Operational taxonomic units' (OTUs) clustering percent was set at $97 \%$, with threshold for de novo OTUs creation set at $80 \%$ and minimum reads occurrence at five. Alpha diversity was calculated based on the number of OTUs and Chao 1 bias-corrected. Beta diversity (Principal Component Analysis) was calculated by Bray-Curtis matrix.

\subsection{Calculations and statistics}

\subsubsection{Free ammonia}

Free ammonia concertation was calculated with Eq. (1):

$$
\mathrm{FAN}=\mathrm{TAN} /\left(1+10^{-\mathrm{pH}} / \mathrm{K}_{\mathrm{a}}\right)
$$


Where $\mathrm{K}_{\mathrm{a}}$ is the dissociation constant with the value of $1.29 \times 10^{-9}$ at $37^{\circ} \mathrm{C}$.

\subsubsection{Statistical analysis}

All statistics and figures were performed using the Origin software (OriginLab Corporation, USA). Descriptive statistics were carried out for all variables, mean values and standard deviations were calculated. Pearson correlation and hierarchical clustering analyses were carried out using Multiexperiment viewer (MeV4.9.0).

\section{Results and discussion}

\subsection{Reactors' performance}

$\mathrm{P} 1$, where an average methane yield of $345 \pm 40$ and $391 \pm 59 \mathrm{~mL} \mathrm{CH}_{4} / \mathrm{g}$ VS was observed for R1 and R2, respectively, was used as baseline phase (no ammonia addition) to evaluate the reactors' performance in the following ammonia acclimatization phases (P2-P7). During P2 to P5, both reactors experienced inhibition with an average loss of $15 \%$ of the methane yield compared to P1 (Fig. 1a). While at P6 $\left(8.5 \mathrm{~g} \mathrm{NH}_{4}{ }^{+}-\mathrm{N} / \mathrm{L}\right)$ the methane production of both reactors, recovered with methane yields constantly above $94 \%$ compared to P1. Specifically, during P6 the average methane production yields did not change significantly and were $332 \pm 37$ and $369 \pm 41 \mathrm{~mL} \mathrm{CH}_{4} / \mathrm{g}$ VS for R1 and R2, respectively. However, when ammonia was increased to $9.5 \mathrm{~g} \mathrm{NH}_{4}{ }^{+}-\mathrm{N} / \mathrm{L}$ (P7), both reactors' yields were reduced by more than $15 \%$ and the $\mathrm{AD}$ process operated under an "inhibited steady state". This stable but suboptimal steady-state is known as an ammonia induced "inhibited steady-state" and is a typical characteristic of many full-scale reactors that operate under high ammonia levels (Benabdallah El Hadj et al., 2009). Even though, there was a clear reduction of methane production at P7, it was significantly less than 
expected compared to previous studies. For example, Moestedt et al. (2016) have reported a $50 \%$ decrease could be observed in methane production of a mesophilic reactor when

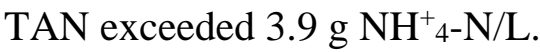

The VFA accumulation in the two reactors was evolved mostly as expected, based on the methane production (Fig. 1b). Specifically, the VFA levels raised up to $4000 \mathrm{mg}$ $\mathrm{HAc} / \mathrm{L}$ at the end of $\mathrm{P} 2$, but decreased rapidly at the beginning of $\mathrm{P} 3$ due to the acclimatization (Tian et al., 2018a) and remained at low levels until P6. Stepwise ammonia acclimatization has been demonstrated before in co-digestions of manure and protein-rich substrates such as microalgae (Angelidaki and Ahring, 1993a). However, this was the first time that continuous $\mathrm{AD}$ reactors could acclimatize to this extreme ammonia levels $\left(7 \mathrm{~g} \mathrm{NH}_{4}{ }^{+}-\mathrm{N} / \mathrm{L}\right)$ while mono-digesting the OFMSW.

During P6, despite the fact that methane production was stable and above 94\% compared to P1, the VFA levels increased and remained above the defined threshold of 1500 mg HAc/L for a "healthy” AD process in CSTR reactors (De Vrieze et al., 2017). It appears that the $8.5 \mathrm{~g} \mathrm{NH}_{4}{ }^{+}-\mathrm{N} / \mathrm{L}$ (P6) was the threshold to the acclimatization process, which could be attributed to the FAN attained at this period (> $800 \mathrm{mg} \mathrm{NH}-\mathrm{N} / \mathrm{L}$ and 8.0 \pm 0.2 , respectively, Fig. 2a). It is generally accepted that FAN is the most toxic form of ammonia, which has positive correlation with $\mathrm{pH}$ (Fig. 2b) (Angelidaki and Ahring, 1993b). Thus, despite that both reactors were acclimatised to more than tenfold higher FAN levels ( $\mathrm{P} 1$ to $\mathrm{P} 5,<50$ to $>500 \mathrm{mg} \mathrm{NH} 3-\mathrm{N} / \mathrm{L}$, respectively), FAN concentrations above $700 \mathrm{mg} \mathrm{NH} 3-\mathrm{N} / \mathrm{L}$ were found to be very toxic for AD processes (Xu et al., 2014).

Finally, the VFA accumulation during P7 was severe and both reactors exceeded 4000 mg HAc/L, which is a clear indicator of an AD process failure ( $\mathrm{Lv}$ et al., 2018). Interestingly, even at these extremely high ammonia levels, the acclimatized microbiome 
of the reactors was able to perform at high efficiency levels (methane production around $85 \%$ compared to P1).

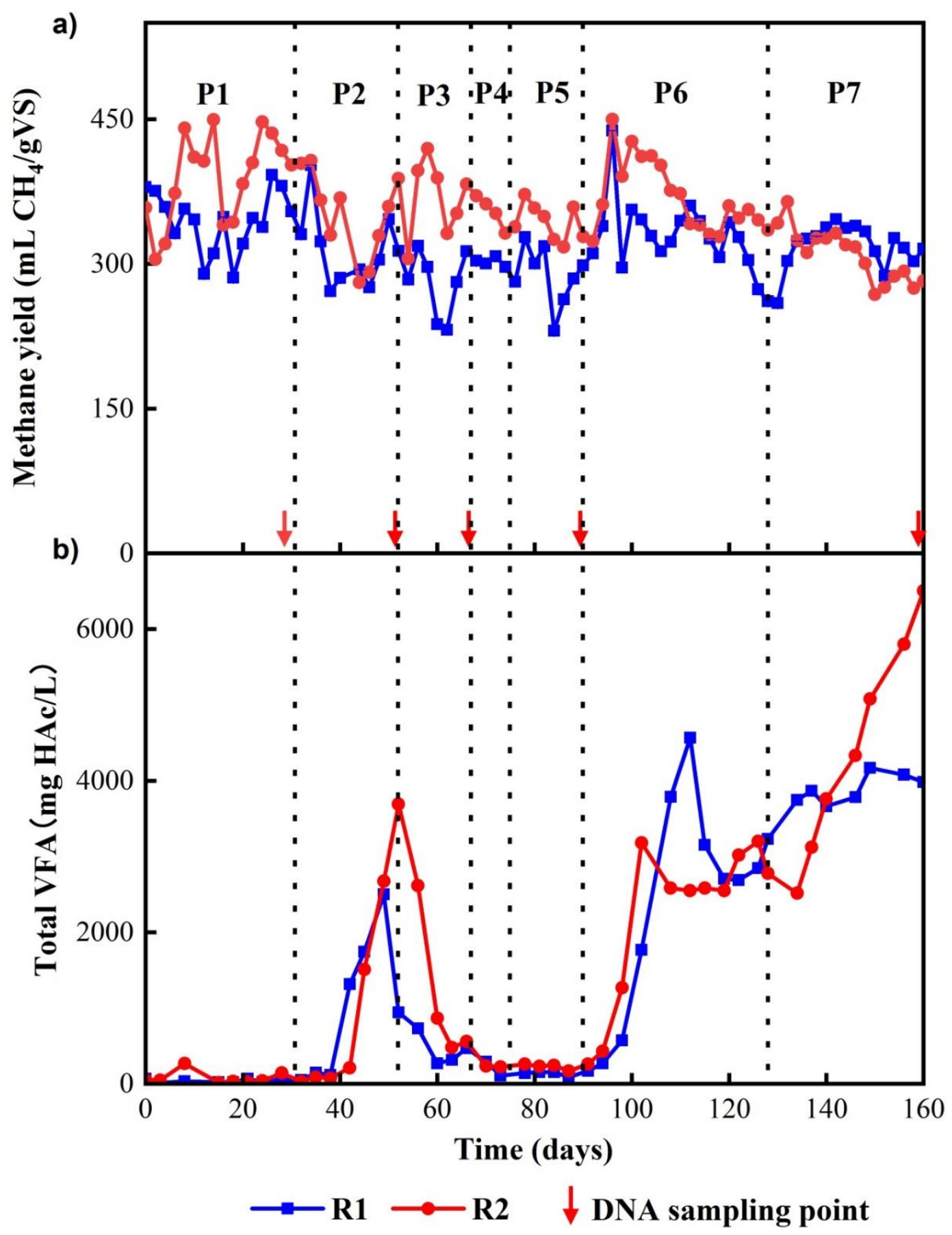

Figure 1. a) $\mathrm{CH}_{4}$ production, and b) VFA variation throughout the experimental period. 


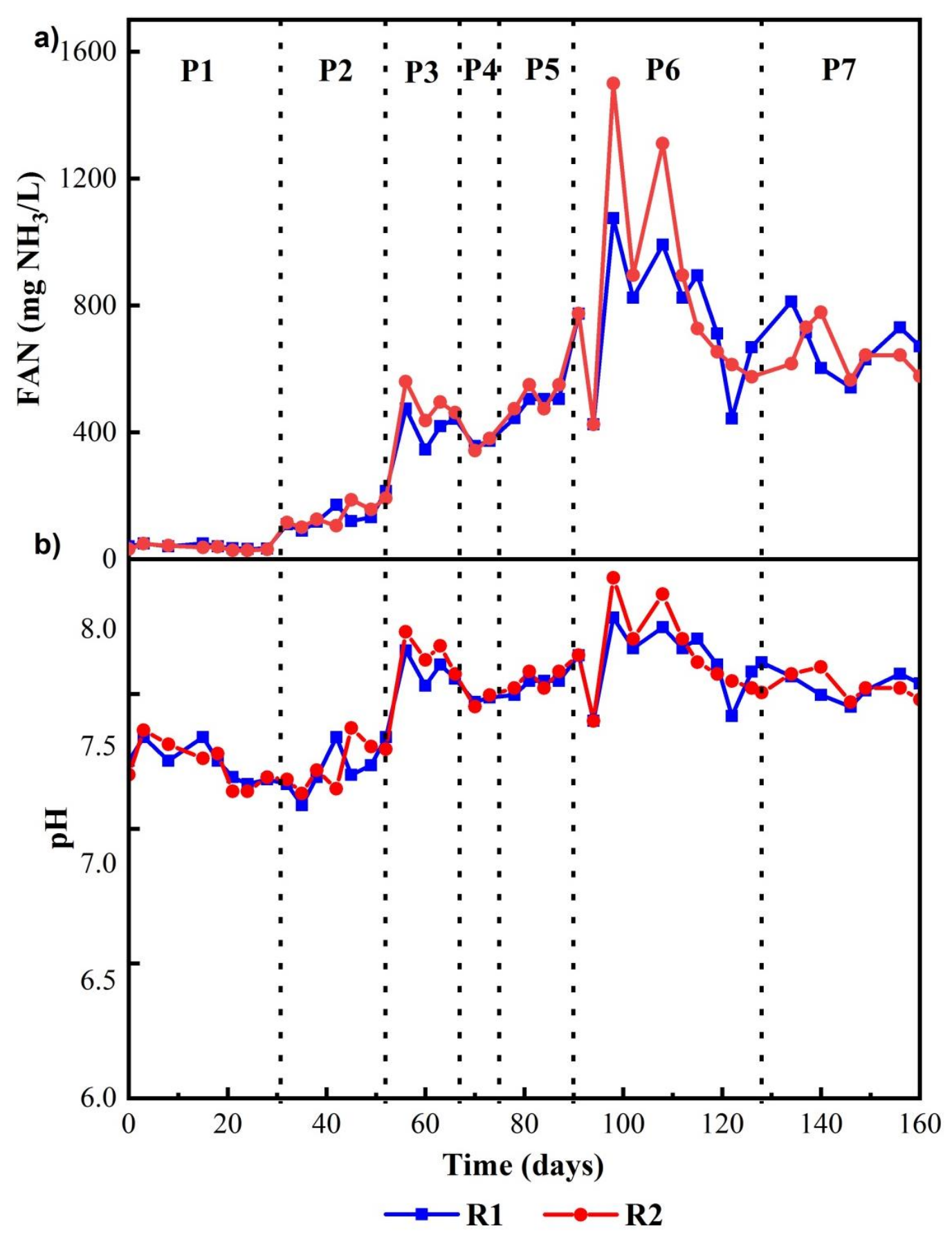

Figure 2. a) FAN, b) pH throughout the experimental period. 


\subsection{Global microbial dynamics}

$16 \mathrm{~S}$ rRNA sequencing was used to elucidate the responses of the microbial community to the increased ammonia concentrations. Alpha diversity based on Chao 1 bias-corrected index (Fig. 3a) showed slight increase at P2 and stable trend alongside the increase of ammonia levels until P6. Afterwards, a sharp decrease of their alpha diversity was observed at P7, which indicated that ammonia increase from 8.5 to $9.5 \mathrm{~g} \mathrm{NH}_{4}{ }^{+}-\mathrm{N} / \mathrm{L}$, was enough to washout approximately $12.5 \%$ of the microbial species from the reactors based on Chao 1 bias-corrected index. At the same time, Beta diversity (Fig. 3b) showed a clear microbial dynamic trend throughout the experimental process. Specifically, longest matrix distances were found between P1 and P7 for both reactors, followed by the one between P6 and P7. This indicated that when ammonia concentration exceeded 8.5 $\mathrm{g} \mathrm{NH}_{4}{ }^{+}-\mathrm{N} / \mathrm{L}$, it drove the microbiome clustering shift (De Vrieze et al., 2017). According to De Vrieze (2017), high diversity and redundancy of microbial community (i.e. as detected from P1 to P6) was considered an effective strategy as buffer against ammonia inhibition, ensuring continuation of methane production, maintaining functionality or metabolic flexibility (Steinhaus et al., 2007). The sudden decrease of alpha diversity from P6 to P7 could have contributed rendering the reactors to become vulnerable to ammonia toxicity. Inhibition was confirmed by the accumulation of VFA (> $4000 \mathrm{mg} \mathrm{HAc} / \mathrm{L})$ and decrease of methane production $(<312 \mathrm{~mL} \mathrm{CH} 4 / \mathrm{g} \mathrm{VS})$ during P7. Therefore it is clear that the toxicity threshold of the two CSTR reactors, based on production performance and microbial activity, for this specific ammonia acclimatization process was $8.5 \mathrm{~g} \mathrm{NH}_{4}{ }^{+}-\mathrm{N} / \mathrm{L}$. 

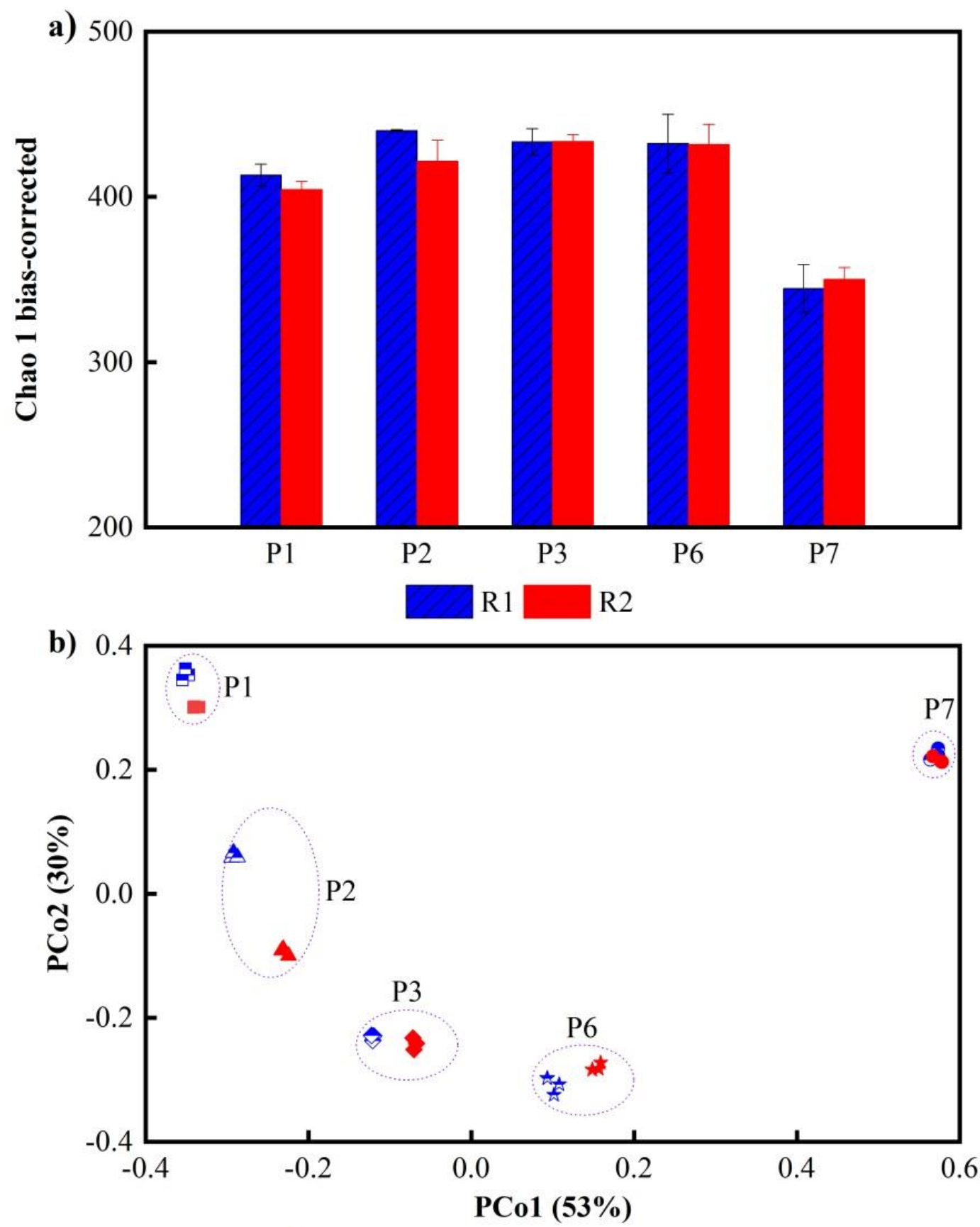

$\Rightarrow \mathrm{R} 1-\mathrm{P} 1 \Delta \mathrm{R} 1-\mathrm{P} 2 \Leftrightarrow \mathrm{R} 1-\mathrm{P} 3 \star \mathrm{R} 1-\mathrm{P} 6 \Leftrightarrow \mathrm{R} 1-\mathrm{P} 7$

- R2-P1 $\Delta$ R2-P2 $\diamond \mathrm{R} 2-\mathrm{P} 3$ * R2-P6 • R2-P7

Figure 3. Alpha Diversity a) based on Chao 1 bias-corrected index; b) Beta diversity of the triplicate samples in R1 and R2. Principal components (PC) 1 and 2 explained 53\% and $30 \%$ of community variation, respectively. 


\subsubsection{Shift in archaea dominance}

Among the archaea, two interesting methanogens changed significantly its abundance from P1 to P7 (Fig. 4), indicating different tolerance capability in respect to ammonia. At P1, the main methanogen was Methanosaeta concilii 2, as a specialist species that uses only acetate, which accounted for more than $70 \%$ of total archaea population in both reactors (Fig. 4). Considering its abundance levels (still higher than 50\% during P2), the dominant role in the archaeal community was well pronounced at medium-low levels of ammonia $\left(<5 \mathrm{~g} \mathrm{NH}_{4}{ }^{+}-\mathrm{N} / \mathrm{L}\right)$. During P3-7, the relative abundance of $M$. concilii 2 decreased alongside the increasing ammonia levels, dropping to $21 \%(\mathrm{P} 3), 5 \%(\mathrm{P} 6)$ and $0 \%$ (P7). It is explained by two reasons: on the one hand, $M$. concilii 2 can use acetate at concentration levels at the range of 5-20 $\mu \mathrm{M}$, however acetate level at P6 was far higher than the optimum range. On the other hand, M. concilii 2 was found to be the most ammonia-sensitive methanogen, which was completely inhibited at $0.56 \mathrm{~g} \mathrm{NH}_{4}{ }^{+}-\mathrm{N} / \mathrm{L}$, primarily due to ammonia's effect on intracellular ion exchange (Ince et al., 2011). Hence, results indicated that there is a negative impact of increasing acetate and ammonia concentrations on $M$. concilii 2 (Tian et al., 2018a).

Conversely, the relative abundance of Methanosarcina soligelidi 1 strongly increased from less than $0.4 \%$ up to more than $94 \%$ in both reactors from P1 to P7. Remarkably, $M$. soligelidi 1 was found to be the most ammonia tolerant methanogen in this study. This finding was in accordance with a previous study, where $M$. soligelidi 1 was the dominant acetoclastic methanogens at extreme ammonia levels (> $\left.7 \mathrm{~g} \mathrm{NH}_{4}{ }^{+}-\mathrm{N} / \mathrm{L}\right)$ (Taubner et al., 2015). The dominant role of M. soligelidi 1 could be justified by several factors. Firstly, it is known that $M$. soligelidi 1 could form clusters of cells in order to reduce the toxicity of ammonia since this formation creates an ammonium gradient from the bulk ammonia 
concentration at the surface along the inner part of the aggregate and thereby lessen the ammonia concentration at the inner core of the sphere (Conklin et al., 2006; Wagner et al., 2013). Secondly, M. soligelidi 1 show remarkable capability of environmental stress tolerance (e.g. freezing, aerobic or dry condition) owning to its intact membrane lipids (Wagner et al., 2013). Thirdly, M. soligelidi 1 is metabolically more versatile (i.e. able to generate $\mathrm{CH}_{4}$ from $\mathrm{H}_{2} / \mathrm{CO}_{2}$, methanol and acetate) than other acetoclastic and hydrogenotrophic methanogens (who are restricted with only carbon substrate) (Li et al., 2017). Additionally, despite the fact that, in many cases, Methanosarcina spp. were found to be more sensitive to ammonia compared to hydrogenotrophic methanogens (Wang et al., 2015; Li et al., 2017; Akindele and Sartaj, 2018); in this study, M. soligelidi 1 was able to become the dominant methanogen. Conversely, the hydrogenotrophic methanogens were found at extremely low abundance. Specifically, the relative abundance of Methanobacterium sp. 3 accounted for $7 \%$ at P1 increased to $18 \%$ at P6, but completely disappeared at $\mathrm{P} 7$, which was similar to the relative abundance of Methanobacteriaceae sp. 5. Methanoculleus palmolei 4 was the only hydrogenotrophic methanogen present at $\mathrm{P} 7$, although at low relative abundance $(2 \%$ of archaeal community).

Considering the dominant ammonia tolerant methanogens are different in previous studies, it seems that dominant methanogens could be different at the same ammonia levels due to the different operating conditions (e.g. substrate, HRT, OLR, pH etc.) (Wang et al., 2015; Akindele and Sartaj, 2018; Capson-Tojo et al., 2018). Based on that (Akindele and Sartaj, 2018) have proposed that the initial archaeal composition of the inoculum plays an important role during the reactor start-up in order to achieve a stable $\mathrm{AD}$ process at high ammonia levels. Hence, we can infer that ammonia is the major but 
not the only driving force to shape the methanogenic communities of the AD processes, the other factors determining the methanogens dominance in digesters need further investigation

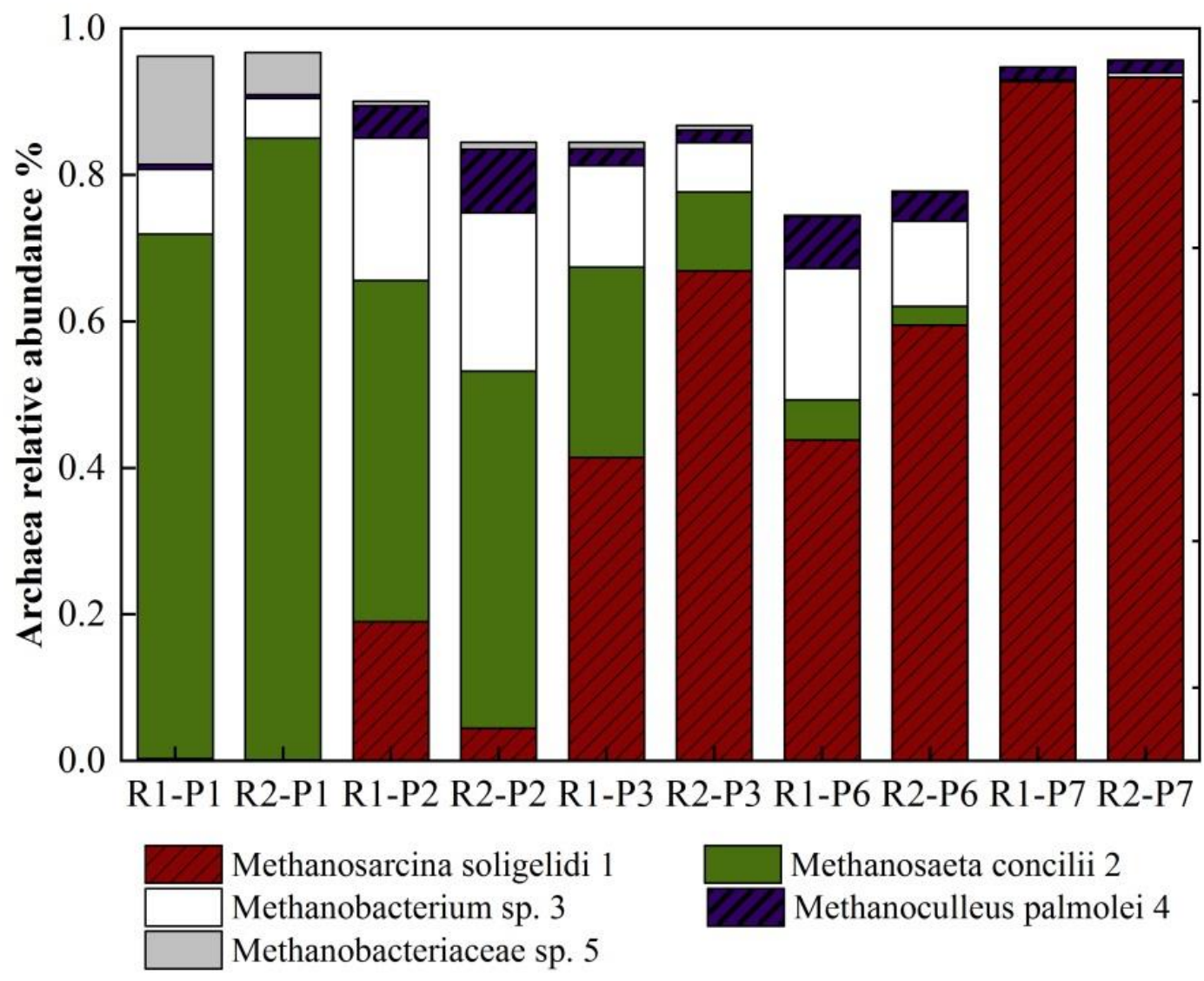

Figure 4. Archaeal relative abundance (\%) in different phases of reactor R1and R2 at species level. 


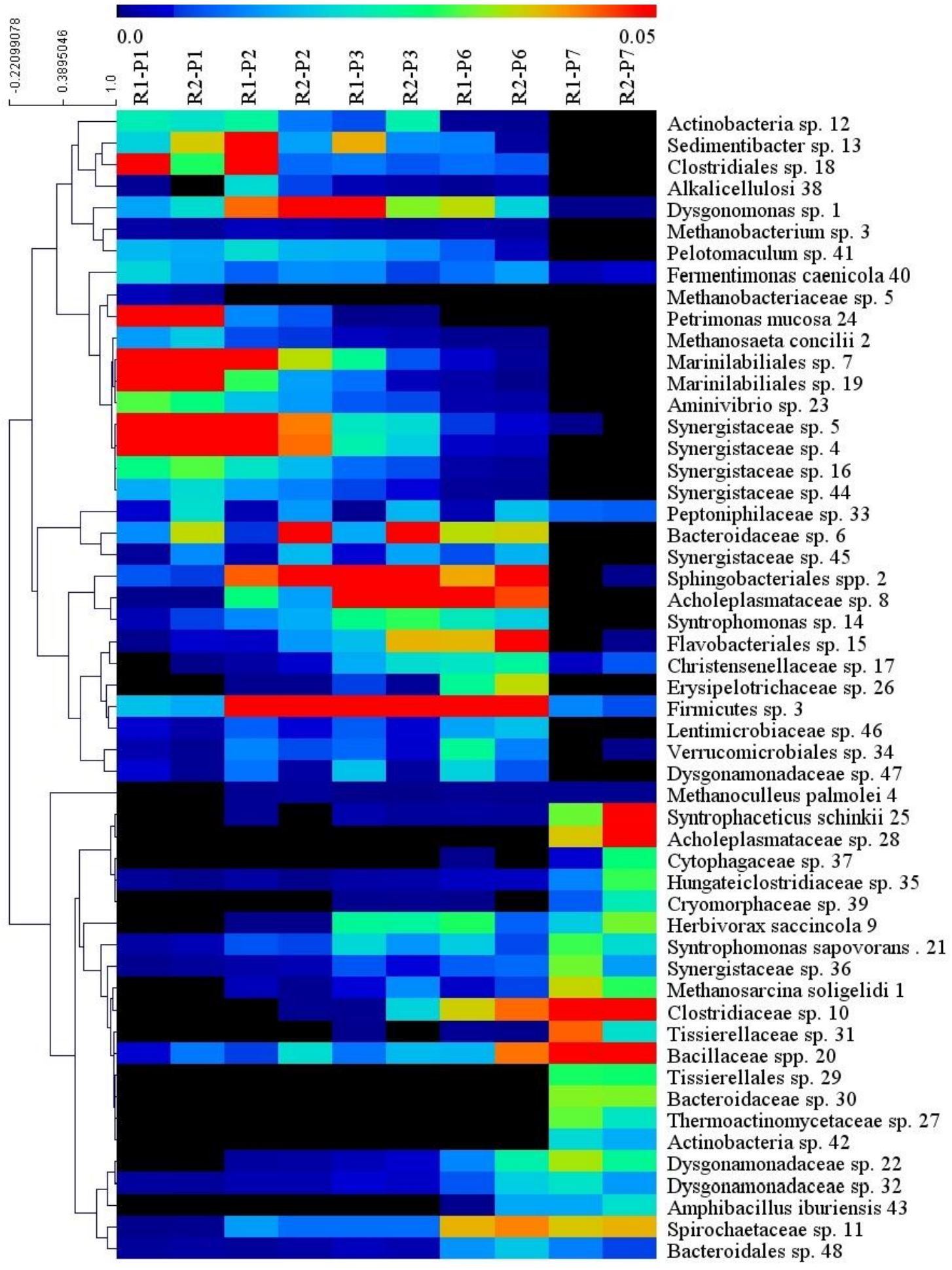

Figure 5. Hierarchical cluster analysis of interesting bacteria and archaea in R1and

$\mathrm{R} 2$ at the different ammonia level. 


\subsubsection{Trends in bacterial populations}

From $\mathrm{P} 1$ to $\mathrm{P} 7$, the addition of ammonia resulted in a dramatic change of the bacterial community (Fig. 5). To be more specific, at P1, the predominant phylum was Bacteroidetes with around $41.80 \%$ of relative abundance, followed by the Synergistetes (24.78\%) and Firmicutes (21.99\%). As the ammonia levels increased, Firmicutes became the most dominant phylum with a relative abundance of $69.12 \%$ at P7. Firmicutes spp., which mediates the acidogenesis step of the AD process, have a recorded robustness to high TAN concentrations (Frank et al., 2016; Chen et al., 2018). On contrary, Bacteroidetes spp. and Synergistetes spp. abundances declined to $15.20 \%$ and $<1 \%$, respectively, at P7; which indicated that both Synergistetes and Bacteroidetes phyla members were vulnerable to the elevated ammonia levels despite the stepwise acclimatization process.

At species-level, the relative abundance of Bacillaceae sp. 20 and Syntrophaceticus schinkii 25 showed a dramatic increase from undetectable levels (prior to P5) to $12 \%(\mathrm{P} 7)$. Bacillaceae sp. 20 was found to be similar to novel uncultured phylotype of syntrophic acetate oxidizing bacteria (SAOB) with 100\% identity (Westerholm et al., 2010); while, Syntrophaceticus schinkii 25 was proposed to be syntrophic partner of a hydrogenotrophic methanogen (e.g. Methanoculleus sp.4), to perform methanogenesis by interspecies hydrogen transfer (Wagner et al., 2013). Thus, the extreme low abundance of strictly hydrogen-utilizing methanogens did not match the increased abundance of these two acetate oxidizing bacteria (SAOB). At the same time, $M$. soligelidi was found to have a faster growth rate on $\mathrm{H}_{2} / \mathrm{CO}_{2}$ compared to acetate (Örlygsson et al., 1996). Thus, it seems that $M$. soligelidi utilised $\mathrm{H}_{2} / \mathrm{CO}_{2}$ to perform methanogenesis in synergy with Bacillaceae sp. 20 and Syntrophaceticus schinkii 25 (SAOBs). Specifically, the low 
abundance of these two SAOBs at P1 to P5 was due to the lack of $\mathrm{H}_{2}$ consumers between P1-P5; therefore, when M. soligelidi shifted to a hydrogenotrophic metabolism, the growth of these two SAOBs was stimulated.

Consequently, other acidogenic bacteria, Clostridiaceae sp. 10 (92\% similarity with Clostridium acetireducens), which exclusively uses acetate during degradation of the branched-chain amino acids and alanine to produce butyrate and $\mathrm{H}_{2}$ (Vartoukian et al., 2007), became the most dominant OTU with relative abundance of $15.5 \%$ at P7. The dominance of this species can be attributed to the unique composition of the reactors, containing both VFA and protein-rich substrates. In addition, two other OTUs with higher ammonia tolerance, i.e. Tissierellales sp. 30 (3\%) and Bacteroidaceae sp. 31 (3.4\%), were observed with high relative abundance at P7. Tissierellales sp. 30 and Bacteroidaceae sp. 31 (90\% and $92 \%$ identity to Sporanaerobacter acetigenes and Bacteroides propionicifaciens, respectively (Wojcieszak et al., 2017)), were reported to be important acetate and $\mathrm{H}_{2}$-producing bacteria (Xia et al., 2014; Wojcieszak et al., 2017). The dominancy of these $\mathrm{H}_{2}$-producing bacteria (e.g. Clostridiaceae sp. 10, Bacillaceae sp. 20 and Syntrophaceticus schinkii 25, Tissierellales sp. 30, Bacteroidaceae sp. 31) was the result of the potential hydrogenotrophic pathway shift of $M$. soligelidi.

Overall, this microbial community redundancy and versatile metabolic pathway were the major reasons to maintain efficient and stable methane production, without loss of functionality or metabolic flexibility during ammonia acclimatization from 1.1 to $7 \mathrm{~g}$ $\mathrm{NH}^{+}{ }_{4-\mathrm{N}} / \mathrm{L}$. Clearly, $8.5 \mathrm{~g} \mathrm{NH}^{+}{ }_{4-\mathrm{N}} / \mathrm{L}$ was a threshold that introduced a suboptimal AD process and subsequently lead to the sharp drop of the microbial diversity at $9.5 \mathrm{~g} \mathrm{NH}^{+} 4$ $\mathrm{N} / \mathrm{L}$. 


\section{Conclusions}

This study demonstrated a successful stepwise acclimatization up to $8.5 \mathrm{~g} \mathrm{NH}_{4}{ }^{+}-\mathrm{N} / \mathrm{L}$ during $\mathrm{AD}$ of the OFMSW. Microbiological analyses showed that ammonia load was identified as the main factor to shape microbial composition. The influence were characterized by a shift from hydrogenotrophic methanogens (e.g. Methanobacterium sp.5) and acetoclastic methanogens (M. concilii, only low-acetate affinity microorganisms) that prevailed in the initial inoculum samples at P1, to the dominance of metabolically more versatile and ammonia more tolerant acetoclastic methanogens $(M$. soligelidi) at extreme ammonia levels. The archaeal shift was essential to keep high biomethanation efficiency.

\section{Acknowledgements}

This work was supported by Energinet.dk under the project framework ForskEL "MicrobStopNH3-Innovative bioaugmentation strategies to tackle ammonia inhibition in anaerobic digestion process" (program no. 2015-12327). We acknowledge financial support from MUDP project "VARGA - VAnd Ressource Genvindings Anlægget". Miao Yan would like to thank for the financial support from China Scholarship Council.

\section{Reference}

[1] Akindele, A.A., Sartaj, M., 2018. The toxicity effects of ammonia on anaerobic digestion of organic fraction of municipal solid waste. Waste Manag 71, 757-766.

[2] Angelidaki, I., Ahring, B., 1993a. Thermophilic anaerobic digestion of livestock waste: the effect of ammonia. Appl Microbiol Biotechnol 38, 560-564. 
[3] Angelidaki, I., Ahring, B.K., 1993b. Thermophilic anaerobic digestion of livestock waste: the effect of ammonia. Appl Microbiol Biotechnol 38, 560-564.

[4] Angelidaki, I., Karakashev, D., Batstone, D.J., Plugge, C.M., Stams, A.J., 2011. Biomethanation and its potential. Methods Enzymol 494, 327-51.

[5] APHA, 2005. Standard Methods for the Examination of Water and Wastewater. American Public Health Association, Washington, DC.

[6] Benabdallah El Hadj, T., Astals, S., Gali, A., Mace, S., Mata-Alvarez, J., 2009. Ammonia influence in anaerobic digestion of OFMSW. Water Sci Technol 59, $1153-8$.

[7] Campanaro, S., Treu, L., Kougias, P.G., Luo, G., Angelidaki, I., 2018. Metagenomic binning reveals the functional roles of core abundant microorganisms in twelve full-scale biogas plants. Water Res 140, 123-134.

[8] Capson-Tojo, G., Trably, E., Rouez, M., Crest, M., Bernet, N., Steyer, J.P., Delgenes, J.P., Escudie, R., 2018. Methanosarcina plays a main role during methanogenesis of high-solids food waste and cardboard. Waste Manag 76, 423430.

[9] Chen, S., He, J., Wang, H., Dong, B., Li, N., Dai, X., 2018. Microbial responses and metabolic pathways reveal the recovery mechanism of an anaerobic digestion system subjected to progressive inhibition by ammonia. Chem Eng J 350, 312-323.

[10] Conklin, A., Stensel, H.D., Ferguson, J., 2006. Growth Kinetics and Competition Between Methanosarcina and Methanosaeta in Mesophilic Anaerobic Digestion. Water Environ Res 78, 486-496. 
[11] De Vrieze, J., Christiaens, M.E.R., Walraedt, D., Devooght, A., Ijaz, U.Z., Boon, N., 2017. Microbial community redundancy in anaerobic digestion drives process recovery after salinity exposure. Water Res 111, 109-117.

[12] Eurostat, 2018. Municipal waste generation. https://ec.europa.eu/eurostat/statisticsexplained/index.php/Municipal_waste_statistics\#Municipal_waste_generation

[13] Fisher, K., 2006. Impact of energy from waste and recycling policy on UK greenhouse gas emissions. Environment Resource Management for Department of Environment, Food and Rural Affairs. Prieiga per internetą: http://randd. defra. gov. uk/Document. aspx.

[14] Frank, J.A., Arntzen, M.O., Sun, L., Hagen, L.H., McHardy, A.C., Horn, S.J., Eijsink, V.G., Schnurer, A., Pope, P.B., 2016. Novel Syntrophic Populations Dominate an Ammonia-Tolerant Methanogenic Microbiome. mSystems 1.

[15] Hoornweg, D., Bhada-Tata, P., 2012. What a waste: a global review of solid waste management. World Bank, Washington, DC.

[16] Ince, B., Koksel, G., Cetecioglu, Z., Oz, N.A., Coban, H., Ince, O., 2011. Inhibition effect of isopropanol on acetyl-CoA synthetase expression level of acetoclastic methanogen, Methanosaeta concilii. J Biotechnol 156, 95-99.

[17] Koster, I.W., Lettinga, G., 1988. Anaerobic digestion at extreme ammonia concentrations. Biological Wastes 25, 51-59.

[18] Li, N., Xue, Y., Chen, S., Takahashi, J., Dai, L., Dai, X., 2017. Methanogenic population dynamics regulated by bacterial community responses to protein-rich organic wastes in a high solid anaerobic digester. Chem Eng J 317, 444-453. 
[19] Liu, Z., Dang, Y., Li, C., Sun, D., 2015. Inhibitory effect of high NH4+-N concentration on anaerobic biotreatment of fresh leachate from a municipal solid waste incineration plant. Waste Manage 43, 188-195.

[20] Lv, Z., Leite, A.F., Harms, H., Glaser, K., Liebetrau, J., Kleinsteuber, S., Nikolausz, M., 2018. Microbial community shifts in biogas reactors upon complete or partial ammonia inhibition. Appl Microbiol Biotechnol.

[21] Moestedt, J., Muller, B., Westerholm, M., Schnurer, A., 2016. Ammonia threshold for inhibition of anaerobic digestion of thin stillage and the importance of organic loading rate. Microb Biotechnol 9, 180-94.

[22] Nielsen, H.B., Angelidaki, I., 2008. Strategies for optimizing recovery of the biogas process following ammonia inhibition. Bioresour Technol 99, 7995-8001.

[23] Schnürer, A., Nordberg, Å., 2008. Ammonia, a selective agent for methane production by syntrophic acetate oxidation at mesophilic temperature. Water Sci Technol 57, 735-740.

[24] Sprott, G.D., Patel, G.B., 1986. Ammonia toxicity in pure cultures of methanogenic bacteria. Syst Appl Microbiol 7, 358-363.

[25] Steinhaus, B., Garcia, M.L., Shen, A.Q., Angenent, L.T., 2007. A Portable Anaerobic Microbioreactor Reveals Optimum Growth Conditions for the Methanogen \&lt;em\&gt;Methanosaeta concilii\&lt;/em\&gt. Appl Environ Microbiol 73, 1653.

[26] Taubner, R.-S., Schleper, C., Firneis, M.G., Rittmann, S.K.M.R., 2015. Assessing the Ecophysiology of Methanogens in the Context of Recent Astrobiological and Planetological Studies. Life (Basel, Switzerland) 5, 1652-1686. 
[27] Tian, H., Fotidis, I.A., Mancini, E., Angelidaki, I., 2017. Different cultivation methods to acclimatise ammonia-tolerant methanogenic consortia. Bioresour Technol 232, 1-9.

[28] Tian, H., Fotidis, I.A., Mancini, E., Treu, L., Mahdy, A., Ballesteros, M., GonzalezFernandez, C., Angelidaki, I., 2018a. Acclimation to extremely high ammonia levels in continuous biomethanation process and the associated microbial community dynamics. Bioresour Technol 247, 616-623.

[29] Tian, H., Karachalios, P., Angelidaki, I., Fotidis, I.A., 2018b. A proposed mechanism for the ammonia-LCFA synergetic co-inhibition effect on anaerobic digestion process. Chem Eng J 349, 574-580.

[30] Vartoukian, S.R., Palmer, R.M., Wade, W.G., 2007. The division "Synergistes". Anaerobe 13, 99-106.

[31] Wagner, D., Schirmack, J., Ganzert, L., Morozova, D., Mangelsdorf, K., 2013. Methanosarcina soligelidi sp. nov., a desiccation- and freeze-thaw-resistant methanogenic archaeon from a Siberian permafrost-affected soil. Int J Syst Evol Microbiol 63, 2986-91.

[32] Wang, H., Fotidis, I.A., Angelidaki, I., 2015. Ammonia effect on hydrogenotrophic methanogens and syntrophic acetate-oxidizing bacteria. FEMS Microbiol Ecol 91.

[33] Westerholm, M., Roos, S., Schnurer, A., 2010. Syntrophaceticus schinkii gen. nov., sp. nov., an anaerobic, syntrophic acetate-oxidizing bacterium isolated from a mesophilic anaerobic filter. FEMS Microbiol Lett 309, 100-4.

[34] Wiegant, W.M., Zeeman, G., 1986. The mechanism of ammonia inhibition in the thermophilic digestion of livestock wastes. Agricultural Wastes 16, 243-253. 
[35] Wojcieszak, M., Pyzik, A., Poszytek, K., Krawczyk, P.S., Sobczak, A., Lipinski, L., Roubinek, O., Palige, J., Sklodowska, A., Drewniak, L., 2017. Adaptation of Methanogenic Inocula to Anaerobic Digestion of Maize Silage. Frontiers in Microbiology 8.

[36] Xia, A., Cheng, J., Ding, L., Lin, R., Song, W., Zhou, J., Cen, K., 2014. Effects of changes in microbial community on the fermentative production of hydrogen and soluble metabolites from Chlorella pyrenoidosa biomass in semi-continuous operation. Energy 68, 982-988.

[37] Xu, Z., Zhao, M., Miao, H., Huang, Z., Gao, S., Ruan, W., 2014. In situ volatile fatty acids influence biogas generation from kitchen wastes by anaerobic digestion. Bioresour Technol 163, 186-92.

[38] Örlygsson, J., Krooneman, J., Collins, M.D., Pascual, C., Gottschall, J.C., 1996. Clostridium acetireducens sp. nov., a Novel Amino Acid-Oxidizing, AcetateReducing Anaerobic Bacterium. Int J Syst Evol Microbiol 46, 454-459. 


\section{Figure Legends}

1 Figure 1. a) $\mathrm{CH}_{4}$ production, and b) VFA variation throughout the experimental period.

2 Figure 2. a) FAN, b) $\mathrm{pH}$ throughout the experimental period.

3 Figure 3. Alpha Diversity a) based on Chao 1 bias-corrected index; b) Beta diversity of the triplicate samples in R1 and R2. Principal components (PC) 1 and 2 explained $53 \%$ and $30 \%$ of community variation, respectively.

6 Figure 4. Archaeal relative abundance (\%) in different phases of reactor R1and R2 at 7 species level.

8 Figure 5. Hierarchical cluster analysis of interesting bacteria and archaea in R1and R2 at 9 the different ammonia level. 